\title{
Beta-Blocker Measurement
}

National Cancer Institute

\section{Source}

National Cancer Institute. Beta-Blocker Measurement. NCI Thesaurus. Code C75383.

The determination of the amount of any beta-blocker present in a sample. 